Title: Study of the trophic web of San Simón Bay (Ría de Vigo) by using stable isotopes.

\author{
Authors: R. Filgueira* and B.G. Castro \\ *Corresponding author
}

\author{
Addresses: \\ R. Filgueira \\ Consejo Superior de Investigaciones Científicas (CSIC) - Instituto de Investigaciones Marinas. \\ c/Eduardo Cabello 6, 36208 Vigo, Spain; tel.: +34 986 231930; fax: +34 986 292762; e-mail: \\ ramonf@iim.csic.es \\ Present address: \\ Department of Oceanography, Dalhousie University, Halifax, NS B3H 4J1, Canada
}

B.G. Castro

Universidad de Vigo

Facultad de Ciencias del Mar, Campus Lagoas-Marcosende, 36310 Vigo, Pontevedra, Spain; tel: +34 986 812623; fax: +34 986 812556; e-mail: bcastro@uvigo.es.

\title{
Contribution to the work:
}

Both authors contributed in all processes related to study design, analysis and writing. 


\section{ABSTRACT}

Based on the stable isotope composition in ${ }^{15} \mathrm{~N}$ and ${ }^{13} \mathrm{C}$ of different potential sources of organic matter and consumers of an intertidal Zostera marina meadow located in San Simón Bay (Ría de Vigo, NW of Spain), a simplified food web of this community was reconstructed. For this purpose, some alternatives in different steps of the most used methodology of stable isotope dietary analysis was developed that copes with some of the limitations associated to the interpretation of isotopic signals for food web analysis, those of uncertainty on the fractionation value, mathematical model to use for the diet resolution and shortage of the isotope number for discriminating many food sources. The application of this protocol to the studied community reported similar results to those from other studies based on similar trophic webs, emphasizing the importance of local primary producers, especially microphytobenthos, which could be available for several primary consumers through resuspension forced by tidal hydrodynamic. The good agreement with previous results suggests that the proposed protocol is a feasible alternative to elucidate the most plausible trophic relationships in complex trophic webs using stable isotopes analysis.

KEYWORDS: stable isotope, food web, diet analysis, seagrass, Ría de Vigo. 


\section{INTRODUCTION}

A trophic web describes the feeding behaviour of the organisms in a community (Cohen et al., 1990). From a functional point of view, a web represents the different consumer-resource relationships in the community and the pathways of matter and energy transfer in the ecosystem. Elucidating these relationships is crucial to understanding how ecosystems work as well as predicting potential effects that different stressors such as human activity have on ecosystems (Winemiller and Polis, 1996). Usually, reconstruction of a trophic web is based on the study of anatomic structures related to feeding, direct observation of consumption and the analysis of gut contents (Polunin and Pinnegar, 2002). These methods have limited utility because they can only resolve recent feeding events, and reveal nothing about an organism's long term feeding history. They also require a large number of samples and are very difficult to apply to small consumers or to easily digestible diets. Alternative methods have recently been developed that improve and complement the previous ones (Sheppard and Harwood, 2005; De Lange and Van den Brink, 2006; Carreon-Martinez and Heath, 2010). One such method is the analysis of consumer's stable isotopes ratios. This technique finds potential sources of organic matter exploited by the consumer based on the principle "you are what you eat", which assumes that the isotopic composition of a consumer's body tissue is a direct consequence of the isotopic composition of its food sources (DeNiro and Epstein, 1978). Stable isotopes provide long-term information about a consumer's diet without requiring large sampling periods, and in addition can be applied to all organic matter sources and consumer sizes. 
The assimilation of food particles by the consumer causes that the consumer isotopic composition reflects the isotopic composition of the food sources (Fry and Parker, 1979; Haines and Montague, 1979). However, differences in the physical-chemical properties and chemical reaction rates between isotopes cause an enrichment in the proportion of heavier isotopes in the consumer compared to the food sources (Ponsard and Arditi, 2000), in a process is called fractionation (Libes, 1992). By examining the isotopic ratios of various organisms in an ecosystem and accounting for fractionation, trophic ecologists can trace organic matter sources on a community (Peterson et al., 1984; Riera et al., 2000), estimate the trophic level of an organism (Vander Zanden and Rasmussen, 1999; Post et al., 2000) and reconstruct diets and trophic web of a community (Hughes et al., 2000; Pinnegar and Polunin, 2000; Ponsard and Arditi, 2000).

However, using stable isotopes to study trophic ecology presents limitations: (1) The degree to which fractionation occurs depends on different variables such as ecosystem type (France and Peters, 1997), trophic level (Vander Zanden and Rasmussen, 2001) and food source (Fantle et al., 1999; Adams and Sterner, 2000). (2) There is no universal methodology for reconstructing diet from stable isotopes, and the assumptions of commonly employed models are at odds with one another. For example, linear mixing models assume that the consumer isotopic composition, after correcting for fractionation, is a linear combination of the isotopic composition of all food sources weighted by their relative contributions to the diet (Fry and Sherr, 1984). Meanwhile, Euclidean distance models calculate the contribution of each food source depending on the Euclidean distance between the source and the consumer in a space defined by the isotopic 
composition. This model assumes that the isotopic composition of the consumer cannot be determined a priori based on the isotopic composition and relative contribution of the different sources because the ecological and biological processes do not allow the prediction of the result (Ben-David and Schell, 2001). (3) Linear mixing models are additionally restricted in that they can only discriminate between a limited numbers of food sources, $n+1$ where $n$ is the number of studied isotopes.

These limitations are especially significant in trophic web studies where seagrasses are involved given the complexity of the trophic relationships associated to these ecosystems. Seagrasses meadows are considered areas of special interest given the high productivity and biodiversity as well as their role as "ecosystem engineers" (Marbà et al., 2006). The complexity of the threedimensional structure created by Zostera leafs offers protection from predators and environmental stressors, increasing the biodiversity of these areas (Hemminga and Duarte, 2000). In addition, this structure is maintained by a dynamic balance between the death and formation of new leafs, which contributes significantly to carbon recycling (Törnblom and Sondegaard, 1999). The high productivity derived from this dynamic balance, increased by the microphytobenthos associated to these areas, can dominate the primary production in shallow coastal environments (Törnblom and Sondegaard, 1999). Therefore, the high biodiversity of organisms in these ecosystems results in complex trophic webs involving several food sources, including allochthonous terrestrial and marine inputs, autochthonous primary production and likely the seagrass itself by direct consumption or through channelization by detritivores (Törnblom and Sondegaard, 1999; Hemminga and Duarte, 2000). The high number of potential 
organic matter sources and the high diversity of trophic relationships both increase the uncertainty in the use of the limited number of isotopes in trophic web studies. In the present study the trophic web of a Zostera marina seagrass meadow located in an estuary area in the San Simón Bay, in the inner part of Ría de Vigo (NW Spain), is described using the stable isotopes ${ }^{13} \mathrm{C}$ and ${ }^{15} \mathrm{~N}$. The trophic web of this ecosystem was reconstructed by finding the isotopic composition of many different organic matter sources and multiple consumer species with different feeding behaviours. This study suggests some alternatives in different steps of the most used methodology for studying trophic webs, revisiting well-known concepts and working in the direction of the limitations described previously, i.e. fractionation uncertainty, mathematical model and limitation on the number of isotopes. In this way, the goal of the protocol is to find the most plausible trophic relationships rather than provide a detailed and quantitative description of each consumer's diet..

\section{MATERIAL AND METHODS}

\section{$\underline{2.1 \text { Study area }}$}

San Simón Bay is located in the inner part of the Ría de Vigo (Fig. 1), and is 7 km long and 2.5 $\mathrm{km}$ wide, occupying a total area of, $19.5 \mathrm{~km}^{2}$. Tidal range is 2-4 $\mathrm{m}$ (mesotidal), semidiurnal periodicity and hydrodynamic conditions are low energy due to the morphology of the Rande Strait and the shallowness of the bay (Álvarez-Iglesias et al., 2006). The main freshwater input comes from the Oitavén-Verdigo River, with a mean annual discharge of $17.3 \mathrm{~m}^{-3} \mathrm{~s}^{-1}$ (ÁlvarezIglesias et al., 2006). The average depth is less than $7 \mathrm{~m}$, reaching $30 \mathrm{~m}$ in the Rande Strait. An 
extensive intertidal flat dominated by the seagrass Zostera marina dominates the Eastern bank of the bay, which is influenced by the Oitavén-Vergudo River. Different towns and villages are placed around the bay, reaching a population of 40,000 people, being the $85 \%$ located in the Eastern bank. Although there are three main population centers in the bay, there is a continuous mosaic of houses along the coast.

\subsection{Collection and preparation of samples}

Samples were chosen to characterize several sources of organic matter in the bay as well as consumers with different feeding behaviour and trophic level. Marine Particulate Organic Matter (POM) was collected inside of the bay in a station close to Rande Strait $\left(42^{\circ} 17^{\prime} 37^{\prime \prime} \mathrm{N}\right.$ 8³8'43'W). Terrestrial Particulate Organic Matter was collected in Oitavén-Verdugo River $\left(42^{\circ} 20^{\prime} 35^{\prime}{ }^{\prime} \mathrm{N} 8^{\circ} 34^{\prime} 21^{\prime \prime} \mathrm{W}\right)$. Sessile species and other ones with limited mobility were collected at three stations on the east bank of the bay $\left(42^{\circ} 19^{\prime} 12^{\prime \prime} \mathrm{N} 8^{\circ} 36^{\prime} 59^{\prime \prime} \mathrm{W} ; 42^{\circ} 19^{\prime} 26^{\prime \prime} \mathrm{N} 8^{\circ} 36^{\prime} 59^{\prime \prime} \mathrm{W}\right.$; $42^{\circ} 19^{\prime} 29^{\prime}$ 'N $8^{\circ} 36^{\prime} 57^{\prime}$ 'W). Mobile species were collected in the area delimited by those three stations. We attempted to collect all samples in triplicate with seasonal periodicity (February, May, July and October 2000 and February and May 2001), although it was not always possible to collect all of them. Each replicate of each species consisted of several individuals, with the exception of POM and Sepia officinalis, which were analyzed individual by individual. The results presented in this study are the average of the six sampling periods and hence represent annual means rather than seasonal periodicity.

\subsubsection{Sources of Organic Matter}




\subsubsection{Marine Particulate Organic Matter}

Three size fractions $(>200 \mu \mathrm{m}, 20-200 \mu \mathrm{m}$ and $<20 \mu \mathrm{m})$ were sampled. The two largest fractions were collected using a phytoplankton net towed from the bottom to the surface. The samples were transferred to a vial where $10 \mathrm{ml} \mathrm{HCl} 1 \mathrm{~N}$ were added to eliminate inorganic carbonate. The vial was shook for few seconds until the effervescence cessation. After that, the samples were transferred to a pre-burned $\left(24 \mathrm{~h}, 550^{\circ} \mathrm{C}\right) \mathrm{GFF}$ filter. After that, they were dried $\left(60{ }^{\circ} \mathrm{C}\right)$ until a constant weight was achieved and ground to below $100 \mu \mathrm{m}$ in a mixer ball mill $\left(\right.$ Retsch $^{\circledR}$ Mixer Mill MM 200) in order to guarantee homogenization (the drying and grounding processes are common to all samples).

The smallest fraction was collected at the peak chlorophyll depth using Niskin bottles. The samples were first filtered through a $20 \mu \mathrm{m}$ net, then 51 of sea water were filtered through a preburned GFF and rinsed with $10 \mathrm{ml}$ of $33 \%$ saline solution (milli-Q water and $\mathrm{NaCl}$ - Panreac PA - ACS - ISO) to eliminate sea salts. After drying $\left(60^{\circ} \mathrm{C}\right)$ until a constant weight was achieved, the filters were exposed to an acid atmosphere (HCl Panreac PRS-CODEX 37\%) for 4 $\mathrm{h}$ in order to eliminate inorganic carbonates. Thereafter, the filters were dried again and the surface was scraped to concentrate the sample before grounding.

\subsubsection{Terrestrial Particulate Organic Matter \\ POM samples from 121 of fresh water were pre-filtered by $60 \mu \mathrm{m}$ and the filtrate collected on a pre-burned GFF filter. After that, the filters were dried and exposed to acid atmosphere, following the same protocol used for the smaller fraction of marine POM.}




\subsubsection{Sediment}

$2 \mathrm{dm}^{3}$ of sediment were collected from the top $5 \mathrm{~mm}$ in an area without rocks or macroalgae and sieved through $500 \mu \mathrm{m}$. After an exhaustive homogenization, a subsample was taken and centrifuged ( $3000 \mathrm{rpm}$ for $3 \mathrm{~min}$ at $20^{\circ} \mathrm{C}$ ) to remove interstitial water. $\mathrm{HCl} 1 \mathrm{~N}$ was then added until the effervescence ceased (Nieuwenhuize et al., 1994) and the sample was rinsed several times with Milli-Q water to remove the acid leftovers (Hsieh et al., 2000). After each wash, the sample was centrifuged (3000 rpm for $3 \mathrm{~min}$ at $20{ }^{\circ} \mathrm{C}$ ) and the supernatant was discarded. Finally, the sample was dried and ground.

\subsubsection{Microphytobenthos}

$2 \mathrm{dm}^{3}$ of sediment were collected from the top $2 \mathrm{~mm}$ in an area without rocks or macroalgae. Microphytobenthos extraction and purification was based on the positive phototrophic behaviour of the phytobenthic component of each sample. Extraction was carried out for $24 \mathrm{~h}$ following the method described in Couch (1989), which involves collecting the microphytobenthos in sand that is free of carbonates and organic matter. The sand was rinsed with filtered seawater $(0.22 \mu \mathrm{m})$, and the microphytobenthos was collected in the supernatant that resulted from filtration through $60 \mu \mathrm{m}$ and GFF filters. The GFF filters were exposed to a purification process in which they were disposed over a $60 \mu \mathrm{m}$ filter face down in a glass container with filtered sea water $(0.22$ $\mu \mathrm{m})$, which was held in such a way that its bottom could be illuminated. Given the phototrophic behaviour, the microphytobenthos migrated towards the light, being collected in the filtered seawater that was filtered again through the GFF filter. This process caused a significant 
enrichment in the proportion of microphytobenthos with respect to other particulates. Thereafter, the filters were dried and exposed to acid atmosphere, according to the protocol followed for the smaller fraction of marine POM.

2.2.1.5 Ascophyllum nodosum, Enteromorpha intestinalis, Fucus vesiculosus, Ulva spp. and Zostera marina

After the collection, the surface of each individual was cleaned of epiphytic organisms and detritic particles, then rinsed with $\mathrm{HCl} \mathrm{1N}$ and Milli-Q water (Currin et al., 1995; Sauriau and Kang, 2000; Riera et al., 2000). Thereafter the samples were dried $\left(60^{\circ} \mathrm{C}\right)$ until a constant weight was achieved and ground below $100 \mu \mathrm{m}$ in a blade mill (IKA ${ }^{\circledR}$ A11 Analytical Mill) and a mixer balls mill.

\subsubsection{Consumers}

\subsubsection{Herbivores: Littorina littorea and Littorina obtusata}

In the specific case of L. littorea, two samples were collected from different locations; one from the Z. marina blades and the other from nearby $5 \mathrm{~m}$ high rocks without Z. marina. L. obtusata was only collected over the rocks. The individuals were kept alive for $24 \mathrm{~h}$ in plastic tanks with filtered seawater $(20 \mu \mathrm{m})$ from the same area, with the aim of emptying their gut contents, which can modify the isotopic composition (Newman, 1991). Dead individuals were removed because the decomposition can also alter the isotopic values (Ponsard and Amlou in Ponsard and Arditi, 2000). Thereafter, the shells were removed and the samples were processed as in the case of macroalgae. 
2.2.2.2 Filter-feeders: Cerastoderma edule, Mytilus galloprovincialis, Scrobicularia plana and Ruditapes decussatus

The filter feeders were treated using the same protocol as the herbivores.

\subsubsection{Sub-surface feeder: Arenicola marina}

The sub-surface feeder was treated using the same protocol as the filter feeders and herbivores, however the individuals were kept for $48 \mathrm{~h}$ to guarantee their guts were empty.

\subsubsection{Carnivores: Nucella lapillus, Gobius niger, Symphodus bailloni and Sepia officinalis}

Nucella lapillus treatment followed the same protocol applied to the herbivore collections. In the other cases, only muscle tissue was analyzed given that muscle makes up the majority of the remaining tissue after skeletal tissue is removed, so the isotopic composition of muscle tissue is close to the whole organism composition (Peterson and Fry, 1987; Newman, 1991). After the dissection, an acidification process was carried out to remove any carbonate contamination. $G$. niger and Symphodus bailloni samples were ground in a blade mill, then exposed to an acidification process similar to the sediment. The $S$. officinalis tissue was rinsed first with $\mathrm{HCl}$ $1 \mathrm{~N}$ then several times with Milli-Q water. After individual-by-individual analysis, samples of $S$. officinalis were grouped into three classes depending on dorsal mantle length (DML): small (DML $<67 \mathrm{~mm})$, medium $(67 \mathrm{~mm} \leq \mathrm{DML} \leq 120 \mathrm{~mm})$ and large (DML $>120 \mathrm{~mm})$ because of the size dependent variability in feeding behaviour (Castro and Guerra, 1990). All carnivores samples were ground to a size smaller than $100 \mu \mathrm{m}$ in a blade mill and a mixer balls mill. 


\subsubsection{Omnivores: Gammarus sp. and Palaemon adspersus}

The P. adspersus muscle tissue was dissected, rinsed with $\mathrm{HCl} 1 \mathrm{~N}$ and Milli-Q water and ground. The exoskeleton of Gammarus sp. contains calcium carbonate from seawater and nitrogen compounds from the diet (Bunn et al., 1995), therefore two protocols were performed after grinding the whole sample: one subsample was analyzed without acidification to determine $\delta^{15} \mathrm{~N}$ and another subsample was acidified following the protocol used to determinate $\delta^{13} \mathrm{C}$ in the sediment.

\subsection{Isotope analysis}

Samples ground smaller than $100 \mu \mathrm{m}$ in size were analyzed in an elemental analyzer (Carlo Erba Instruments EA 1108 CHNS/O) followed by an isotope-ratio mass spectrometer (DELTA ${ }^{\text {plus }}$, Finningan MAT) to measure the carbon and nitrogen content as well as the relative proportion of ${ }^{13} \mathrm{C}$ and ${ }^{15} \mathrm{~N}$. The isotopic relationships were expressed as:

$$
\delta \mathrm{X}=\left(\mathrm{R}_{\text {sample }} / \mathrm{R}_{\text {std }}-1\right) \times 1000(\%)
$$

Where $\delta \mathrm{X}$ is $\delta^{13} \mathrm{C}$ or $\delta^{15} \mathrm{~N}, \mathrm{R}_{\text {sample }}$ is the relationship between ${ }^{13} \mathrm{C}:{ }^{12} \mathrm{C}$ or ${ }^{15} \mathrm{~N}:{ }^{14} \mathrm{~N}$ in the sample and $\mathrm{R}_{\mathrm{std}}$ is the relative abundance of the desired isotope in the standard. The standard was VPDB (Vienna Pee-Dee Belemnite) for $\delta^{13} \mathrm{C}$ and atmospheric nitrogen for $\delta^{15} \mathrm{~N}$. The internal precision of the analyzer was $\pm 0.01 \%$ and the external precision of the analysis was $\pm 0.2 \%$.

\subsection{Diet analysis}


A protocol called "most plausible diet" was developed to estimate the diet of each consumer based on the isotope composition of both consumer and potential food sources. The protocol is based on the following steps:

\section{Step 1. Biological characteristics and available information about the consumer. \\ Given the biological characteristics of the consumer: size, mobility, structures related to feeding, etc. as well as available information about its feeding behaviour and diet, different sources of food were selected as potential components of its diet.}

\section{Step 2. Fractionation.}

The observed fractionation ranges are -0.7 through $9.2 \%$ and -2.1 through $2.8 \%$ for ${ }^{15} \mathrm{~N}$ and ${ }^{13} \mathrm{C}$ respectively (Vander Zanden and Rasmusen, 2001). The common rule is to apply average values based on bibliography, however in this study we suggest the use of a range. In this way, different diets can be observed for the same consumer depending on the used fractionation. Three values were used for each isotope, $0.5,1.0$ and $1.5 \%$ for $\delta^{13} \mathrm{C}$ and 2.2, 3.0 and $3.8 \%$ for $\delta^{15} \mathrm{~N}$.

\section{Step 3. Mathematical modelling: Euclidean distance and linear mixing models.}

The goal of this step was to select all the potential diets of a consumer and grade them according to the plausibility of being the real one of that consumer. For this purpose both linear mixing models and Euclidean distance were applied to each consumer and combination of fractionation established in Step 2. First of all, a linear mixing model (Fry and Sherr, 1984, Phillips and Cregg, 
2001) was applied to each consumer, after correcting the fractionation, selecting all the combinations of food sources that can mathematically explain the isotopic composition of the consumer. Therefore, only the combinations of sources that can mathematically explain the consumer's isotopic composition are considered in the subsequent step. Each combination of food sources, thereafter called diet, was graded using a Euclidean distance model (Ben-David and Schell, 2001), discriminating the most plausible diet between all of the possible ones. The protocol employed to solve the models changed depending on the number of food sources considered: one, two or three (maximum number of sources using two isotopes).

With one food source, this was considered as a diet if consumer's average isotopic composition, after correcting for fractionation, was within one standard deviation of the food source's isotopic composition for both isotopes; a space that assuming a normal bivariate error, usually takes the form of an ellipse in the plane $\delta^{13} \mathrm{C}-\delta^{15} \mathrm{~N}$ (Fig. 2A). The correlation between $\delta^{13} \mathrm{C}$ and $\delta^{15} \mathrm{~N}$ was taken into account to determine the angle of the ellipse's axes. The Euclidean distance between the average isotopic composition of consumer and source on the plane $\delta^{13} \mathrm{C}-\delta^{15} \mathrm{~N}$ was calculated for each potential diet. This distance was considered inversely proportional to the plausibility of the diet of being the real diet of the consumer.

With two food sources, both were considered to contribute to the diet if the consumer's average isotopic composition, after correcting for fractionation, was included within the space defined by the standard deviation of both sources for both isotopes (Fig. 2B - Consumer 1). Given that the position of the consumer could provide mathematical solutions in which the contribution of one 
source is negative (Fig. 2B - Consumer 2), which makes no biological sense, these solutions were discarded. Using the mixing linear model, the contribution of each source to the diet was calculated for each isotope according to:

$$
\mathrm{X}_{\mathrm{con}}=\mathrm{p}_{1} \mathrm{x} \mathrm{X}_{1}+\mathrm{p}_{2} \mathrm{x} \mathrm{X}_{2}
$$

Where $\mathrm{X}$ is the isotope composition $\left(\delta^{13} \mathrm{C}\right.$ or $\left.\delta^{15} \mathrm{~N}\right)$ of the consumer $($ con $)$ and sources $\left({ }_{1}\right.$ and $\left.{ }_{2}\right)$ and $\mathrm{p}$ the proportion of each source to the consumers' diet, taking into account that $\mathrm{p}_{1}+\mathrm{p}_{2}=1$. Therefore two solutions were available (one per isotope) that were more or less similar to one another depending on the distance from the consumer to the straight line between both sources, which represents the common solutions for both isotopes. This distance to the straight line is assumed to be a consequence of the standard deviation of the sources. In this way, using the calculated proportions and the standard deviation for each source, the theoretical standard deviation of the consumer (Std.Dev.con) can be calculated:

$$
\text { Std.Dev. }{ }_{\cdot{ }^{2}}^{2}=\left(\text { Std.Dev.1 } \mathrm{x} \mathrm{p}_{1}\right)^{2}+\left(\text { Std.Dev.2 } \times \mathrm{p}_{2}\right)^{2}
$$

Where Std.Dev. is the standard deviation for each isotope $\left(\delta^{13} \mathrm{C}\right.$ or $\left.\delta^{15} \mathrm{~N}\right)$ of the consumer (con) and sources $\left({ }_{1}\right.$ and $\left.{ }_{2}\right)$, taking into account that $\mathrm{p}_{1}+\mathrm{p}_{2}=1$. Using these values, the diet calculated previously was discarded if the space defined by the theoretical standard deviation of the consumer for both isotopes did not include the straight line between sources (Fig. 2C). The Euclidean distance between the average isotopic composition of consumer and each source on the plane $\delta^{13} \mathrm{C}-\delta^{15} \mathrm{~N}$ was calculated for each potential diet. For each diet, the sum of the distance between the consumer and each source in the plane $\delta^{13} \mathrm{C}-\delta^{15} \mathrm{~N}$ was calculated and it was considered inversely proportional to the plausibility of the diet of being the real diet of the consumer. 
With three food sources, they were considered as the diet of a consumer if the average composition of this, after correcting for fractionation, can be explained by a linear mixing model in which the contribution of all food sources is positive. This solution in the plane $\delta^{13} \mathrm{C}-\delta^{15} \mathrm{~N}$ is restricted to the space delimited by the averaged isotopic composition of the food sources (Fig. 2D). The Euclidean distance was calculated in the same way as that in the case with two possible food sources.

\section{Step 4. "Most plausible diet"}

Given that several fractionations are used for each isotope and the possibility of diets with one, two or three food sources, it is possible to obtain multiple solutions for each consumer. With the aim of simplifying these results a criterion was suggested, establishing the concept of "most plausible diet". This criterion is based on the following:

1) For each group of diets, depending on the number of food sources considered (1,2 or 3$)$ and the combinations of fractionation (9 possibilities), the diet with a shorter Euclidean distance was selected. Therefore, for each consumer a table was created (Table 1) that contains in the most complex scenario 27 possible diets.

2) The number of times that a food source appeared in a diet was counted. If two or more sources had a statistically (t-student) similar isotopic composition, they were considered as one and were counted together. Finally, the three highest counted sources were considered the "most plausible sources" and define the "most plausible diet" for the given consumer. The others counted sources were considered "less plausible sources". 
Steps 3 and 4 were automated using Visual Basic for Application.

\section{RESULTS}

The average isotopic composition of the organic matter sources and consumers is shown in Table 2. In some cases, the isotopic composition of different sources was statistically similar: $A$. marina and $N$. lapillus $\left(\delta^{13} \mathrm{C}: \mathrm{t}=1.108\right.$, d.f. $=22, \mathrm{p}=0.280 ; \delta^{15} \mathrm{~N}: \mathrm{t}=1.758$, d.f. $\left.=22, \mathrm{p}=0.093\right), A$. nodosum and $C$. edule $\left(\delta^{13} \mathrm{C}: \mathrm{t}=0.356\right.$, d.f. $=26.219, \mathrm{p}=0.725 ; \delta^{15} \mathrm{~N}: \mathrm{t}=0.787$, d.f.=31, $\left.\mathrm{p}=0.437\right), A$. nodosum and S. plana $\left(\delta^{13} \mathrm{C}: \mathrm{t}=1.686\right.$, d.f.=28, $\mathrm{p}=0.103 ; \delta^{15} \mathrm{~N}: \mathrm{t}=0.349$, d.f.=28, $\left.\mathrm{p}=0.729\right), C$. edule and $R$. decussatus $\left(\delta^{13} \mathrm{C}: \mathrm{t}=1.047\right.$, d.f. $=34, \mathrm{p}=0.302 ; \delta^{15} \mathrm{~N}: \mathrm{t}=0.464$, d.f. $\left.=34, \mathrm{p}=0.645\right), E$. intestinalis and $F$. vesiculosus $\left(\delta^{13} \mathrm{C}: \mathrm{t}=0.682\right.$, d.f. $=15.780, \mathrm{p}=0.505 ; \delta^{15} \mathrm{~N}: \mathrm{t}=1.125$, d.f. $=28$, $\mathrm{p}=0.270)$ and $L$. littorea that grows over rocks and L. obtusata $\left(\delta^{13} \mathrm{C}: \mathrm{t}=0.465\right.$, d.f. $=19.414$, $\mathrm{p}=0.647 ; \delta^{15} \mathrm{~N}: \mathrm{t}=1.575$, d.f.=34, $\left.\mathrm{p}=0.125\right)$. These couples cannot be distinguished from a statistical point of view, therefore, when composition in both isotopes is the same, it is not possible to discriminate between them in diet analysis process.

Potential food sources as well as most and less plausible sources for each consumer are summarized in Table 3. In the same way, Figure 3 highlights the most plausible trophic interactions in San Simón Bay.

\subsection{Herbivores: Littorina littorea and Littorina obtusata}

There was a significant difference between the $\delta^{13} \mathrm{C}$ of $L$. littorea growing on a rocky substrate and the $\delta^{13} \mathrm{C}$ of the same species collected on $Z$. marina blades $(\mathrm{t}=8.730$, d.f. $=30, \mathrm{p}<0.001)$, but 
there was no effect of substrate on $\delta^{15} \mathrm{~N}(\mathrm{t}=1.210$, d.f.=30, $\mathrm{p}=0.239)$. All the macroalgae and microphytobenthos were used as potential food sources. The most plausible diet varied depending on the subsrate. In case of L. littorea from rocky substrate the diet included Ulva spp., F. vesiculosus and microphytobenthos, while Ulva spp., F. vesiculosus and Z. marina was the most plausible diet for L. littorea from Z. marina.

The same potential food sources were considered in case of L. obtusata and the most plausible diet was similar to that of $L$. littorea from rocks.

3.2 Filter-feeders: Cerastoderma edule, Mytilus galloprovincialis, Scrobicularia plana and Ruditapes decussatus

All the sources of organic matter with the exception of macroalgae were considered as potential sources of food for filter-feeders. The most plausible diet for C. edule and R. decussatus included the two largest size classes of marine POM and microphytobenthos. M. galloprovincialis had the same diet as the former two species. However, the smallest marine POM fraction was also occasionally selected as a less plausible source for this species. The diet analysis for S. plana only yielded results when one food source, either microphytobenthos or marine POM between 20 and $200 \mu \mathrm{m}$, was considered as a potential diet.

3.3 Sub-surface feeder: Arenicola marina 
Sediment, microphytobenthos and macroalgae were selected as potential food sources for $A$. marina, and the most plausible diet included microphytobenthos, E. intestinalis and $F$. vesiculosus.

\subsection{Carnivores: Nucella lapillus, Gobius niger, Symphodus bailloni and Sepia officinalis \\ L. littorea that grows over rocks, L. obtusata and M. galloprovincialis were selected as potential food sources for $N$. lapillus, and the most plausible diet included M. galloprovincialis and $L$. obtusata. The isotopic composition of L. obtusata is similar to L. littorea, therefore the latter could be included as a plausible food source for N. lapillus.}

Marine POM larger than $200 \mu \mathrm{m}$, herbivores, filter-feeders, A. marina, N. lapillus, P. adspersus and Gammarus sp. were considered potential food sources for G. niger, and the most plausible diet was composed of S. plana, A. marina and L. obtusata. However, N. lapillus and L. littorea could be also considered in the most plausible diet because their isotopic compositions are statistically similar to A. marina and L. obtusata, respectively.

The potential food sources and most plausible diets for S. officinalis depended on the dorsal mantle length (DML). For S. officinalis with DML $<67 \mathrm{~mm}$, marine POM larger than $200 \mu \mathrm{m}$, G. niger, S. bailloni, Gammarus sp. and P. adspersus were considered as potential food sources. The most plausible diet included P. adspersus and marine POM larger than $200 \mu \mathrm{m}$. For other DML sizes the same potential food sources as the smaller size class were considered, although marine POM was changed by S. officinalis smaller than $67 \mathrm{~mm}$. The most plausible diet was $G$. 
niger, Gammarus sp. and P. adspersus for S. officinalis with $67 \mathrm{~mm} \leq \mathrm{DML} \leq 120 \mathrm{~mm}$, while the diet included G. niger and Gammarus sp. for S. officinalis with DML > $120 \mathrm{~mm}$.

\author{
3.5 Omnivores: Gammarus sp. and Palaemon adspersus \\ Sediment, microphytobenthos and macroalgae were considered potential food sources of \\ Gammarus sp., and the most plausible diet was composed of E. intestinalis, sediment and \\ microphytobenthos.
}

Marine POM larger than $200 \mu \mathrm{m}$, microphytobenthos, macroalgae, herbivores, filter-feeders, $A$. marina, N. lapillus, Gammarus sp. and P. adspersus were the potential food sources for $P$. adspersus, The most plausible diet included S. plana, Ulva spp. and L. obtusata. A. nodosum and L. littorea are isotopically similar to S. plana and L. obtusata respectively, therefore they can be considered plausible sources too.

\title{
4. DISCUSSION
}

\section{$\underline{4.1 \text { Diet analysis methodology }}$}

The use of isotope analysis to reconstruct diets presents three methodological problems: (1) choosing the fractionation given the sources of variability that may exert an effect on it, (2) finding the best mathematical model that describes the most plausible diet, and (3) figuring out how to analyze complex trophic webs when the number of potential food sources is higher than $\mathrm{n}+1$, where $\mathrm{n}$ is the number of studied isotopes. 
The fractionation ranges have been established in the literature to be -0.7 through $9.2 \%$ and -2.1 through $2.8 \%$ for ${ }^{15} \mathrm{~N}$ and ${ }^{13} \mathrm{C}$ respectively (Vander Zanden and Rasmusen, 2001), however, the degree of fractionation depends on consumer nutritional status, feeding behaviour (herbivorous vs carnivorous), diet quality, size, age and analyzed tissue (De Niro and Epstein, 1981; Gannes et al., 1998; Fantle et al., 1999; Pinnegar and Polunin, 2000; Adams and Sterner, 2000; Vander Zanden and Rasmussen, 2001; Phillips and Koch, 2002; Post, 2002; Caut et al., 2009), making it difficult to establish the correct value. It is therefore normal to use average values and apply them to different trophic levels, ignoring the well-established uncertainty (eg. Michener and Schell, 1994; Caut et al., 2009). In order to take this variability into account, a range of values was used instead of a single average value: $0.5,1.0$ and $1.5 \%$ for $\delta^{13} \mathrm{C}$ and $2.2,3.0$ and $3.8 \%$ o for $\delta^{15} \mathrm{~N}$. Both the most common values and a confidence interval were considered, which allowed us to establish the different diets for each consumer while taking the variability in fractionation into account. Although these common values of fractionation offer a valuable solution, the ranges of variation for different species can be reduced based on specific experiments, as was suggested by Gannes et al., (1997). In this way, recent studies carried out controlled feeding experiments to determine the isotopic fractionation of different species (e.g. Yokohama et al., 2005 in Mactra veneriformis, Ruditapes phillippinarum, Nihonotrypaea japonica and N. harmandi; Dubois et al., 2007 in Mytilus edulis and Crassostrea gigas; Dang et al., 2009 in Ruditapes phillippinarum). These controlled feeding experiments can reduce the fractionation uncertainty increasing the reliability of the diet resolution, however these studies highlight that the fractionation is species- and tissue-specific, and that the accepted fractionation 
values may not be universally applicable (Yokohama et al., 2005). These results support the approach of using a range of values for fractionation instead of a fixed one.

The mathematical models used in diet resolution are linear mixing models (Fry and Sherr, 1984) and Euclidean distance models (Ben-David and Schell, 2001). In the former, the consumer isotopic composition reflects that of its diet after correcting the fractionation. Therefore, a diet has to mathematically explain consumer isotopic composition according to a linear mixing model that provides the proportion of each food source. Euclidean distance models assume that the isotopic composition of the consumer is influenced by ecological, physiological and biochemical processes (Gannes et al., 1997), therefore a mathematical linear mixing model cannot explain the consumer isotopic composition. These models assume that the contribution of a source to the diet of a consumer is inversely proportional to the distance between the source and the consumer in the $\delta^{13} \mathrm{C}-\delta^{15} \mathrm{~N}$ plane. In addition, the inclusion of a source in the diet is a process previous to the resolution of the model, not a result of the model itself. The protocol suggested in the present paper combines the information reported by both kinds of models, resulting in the definition of the "most plausible diet" (See Material and Methods). The linear mixing model was used to elucidate whether a combination of food sources can be considered as a diet of the consumer and the Euclidean distance model was used to assign different grade of plausibility to each combination of sources. In this process a bivariate normal error distribution was considered instead of the usual rectangular equiprobable region defined by the standard deviation of $\delta^{13} \mathrm{C}$ and $\delta^{15} \mathrm{~N}$. Both approaches provide similar results, however the one used in the present study is more suitable to the statistical theory according to the normal error distribution. In addition, an a 
priori criterion was used to choose the potential food sources depending on biological characteristics and previous knowledge about the consumer.

The third limitation only affects mixing models given that according to the mathematical definition, the maximum number of food sources that can be considered is $n+1$, where $n$ is the number of studied isotopes. The methodology presented in this study addresses the diet resolution in a similar way as a method in the package Isosource, a program developed by Phillips and Greggs (2003), which allows the estimation of the contribution of n different sources to a consumer's diet using linear mixing models. Their method provides the percent contribution of different food sources that were selected a priori as the diet of a consumer. Isosource predicts the isotopic composition for a consumer fed with all possible combinations of sources. The program changes the contribution of each source in small steps, conserving a total contribution of all the sources in $100 \%$. The calculated isotopic composition for the consumer is compared with the real one, accepting the diet as a possible one if both values are included in a predefined tolerance range. Finally, Isosource shows the results of all the possible solutions, which is a range of contributions of each food source to the diet of the consumer. The methodology presented in this study addresses the diet resolution in a similar way as Isosource, considering the combinations of sources that provide a solution using linear mixing models as a diet. However, there are some differences between both methods: (1) Isosource does not take into account standard deviations, therefore it is not possible to find a solution when the consumer isotopic composition is outside the space defined by the average isotopic values of the sources. (2) Isosource allows the fractionation to change, which is one of the most uncertain variables in diet 
analysis. however is does not allow different combinations simultaneously. (3) Isosource provides a range of contributions for each source using linear mixing models. The method described in this study does not provide a range given that is focused on highlighting the most plausible food sources by employing Euclidean distance models, considering an inverse relationship between plausibility and Euclidean distance between food source and consumer in the space defined by the isotopic composition.

The suggested methodology, which considers a priori selection of possible food sources, fractionation uncertainty and the simultaneous use of linear mixing models and Euclidean distance models, allows an objective approach to determine the diet of a consumer avoiding the most important limitations of the stable isotopes technique. However, and like all stable isotopes studies that are used to discriminate objectively between two food sources, this protocol potentially underestimates the contribution of sources with extreme isotopic values. In other words, the closer the food source is to the consumer, the greater the assumed contribution of that source to the consumer's diet. The application of this methodology results in a frequentist approach to highlight the most plausible diet of a consumer.

\subsection{Diet analysis (Table 3, Fig. 3)}

It is well known that stable istope values of both food sources (e.g. Cloern et al., 1992) and consumers (e.g. Malet et al., 2008) change through time, therefore a seasonal approach to elucidate trophic relationships would potentially provide more information about the ecosystem functioning. However, some limitations in "isotopic routing" have to be taken into account to 
analyze seasonally a trophic web using stable isotopes: (1) animals assimilate dietary components with varying efficiencies (Gannes et al., 1997); (2) isotopic fractionation and isotopes turnover rates are not uniform among tissues within an individual (Tieszen et al., 1993; Suring and Wing, 2009) or (3) among species with different physiologies (Suring and Wing, 2009). Therefore, although stable isotope analysis provides long-term information about consumer's diet, this integrative time varies from days to years according to the ecosystem, the species, their growth rate and the tissue considered (Pasquaud et al., 2010), which may obscure the relative importance of dietary components if an animal's diet varies through time (Tieszen et al., 1983). This study is focused in a complex trophic web that contents individuals from different trophic levels, feeding habits, life cycle and life expectancy, which is reflected in their stable isotope values. Therefore a time-averaged approach accumulates this variability through time, minimizing the effect of "isotopic routing" on the diet resolution. This approach is not focused on seasonal dynamics, however it increases the robustness and accuracy in the understanding of the average trophic relationships, providing a general view of the bay's trophic web.

The analysis of diets using stable isotopes depends on the signatures of consumer and sources, therefore a reliable interpretation can only be made if all dietary sources are included in the study (Pitt et al., 2009). This is a limitation of the method and it becomes more important in high trophic levels given that these consumers usually present a wide spectrum of food sources. However, the analysis of all potential food sources is usually impossible to carry out for obvious logistic reasons in complex trophic webs like San Simón Bay. Therefore, the most plausible diets 
summarized in this study present an inherent uncertainty caused by the number of analyzed food sources. In addition, high trophic levels are vulnerable to violate an implicit assumption of stable isotopes technique given that is assumed that the $\mathrm{C}: \mathrm{N}$ ratio of food sources are similar (Phillips and Koch, 2002). However, this can be violated in the case of omnivores. This potential flaw can be analyzed be means of concentration-weighted models (Phillips and Koch, 2002), which are particularly useful for quantifying the contribution of food sources (e.g. Kasai et al., 2004). However, given that the suggested protocol is directed to find the most plausible diet rather than a quantitative description of the diet, this modelling approach was not considered.

\subsubsection{Herbivores: Littorina littorea and Littorina obtusata}

The differences in $\delta^{13} \mathrm{C}$ between $L$. littorea in different intertidal positions could be explained by variability in diet according to food availability. Whereas Ulva spp. and F. vesiculosus are common food sources, individuals that grow over rocks consume microphytobenthos, while individuals from Z. marina consume this plant. Although the presence of Z. marina in the diet of different grazers has been recently reported (Schaal et al., 2008), this is not common in the literature and at most it has been identified as a minor important food source (Jaschinski et al., 2008) given its low digestibility (Nienhuis and Groenendisk, 1986). However, the inclusion of the Z. marina in the most plausible diet of this gastropod could be indirectly caused by consumption of epiphytic organisms of its leaves, which may have an isotopic composition similar to Z. marina (Winning et al., 1999; Jaschinski et al., 2008). The channelization of carbon, nitrogen and phosphorus, and consequently the isotopic marker, from Z. marina to the epiphytes (Hemminga and Duarte, 2000) could explain the L. littorina diet in terms of Ulva spp., $F$. 
vesiculosus and a microalgae. This microalgae would depend on the position of the gastropod on the intertidal, either microphytobenthos or epiphytes for individuals that grow over rocks or $Z$. marina, respectively. In this way, seagrasses are particularly prone to colonization by epiphytic microalgae (Mann, 2000). This most plausible diet is in good agreement with observations in the literature (Lubchenco, 1983; Petraitis, 1983; Barker and Chapman, 1990; Sommer, 2000). In addition, this would represent a non-detritivorous way of introducing Z. marina in the trophic web.

The most plausible diet of L. obtusata is the same as that observed for L. littorea from a rocky substratum, and hence similar to the diets reported in the literature (Hunter, 1981; Hawkins and Hartnoll, 1983; Watson and Norton, 1987).

4.2.2 Filter-feeders: Cerastoderma edule, Mytilus galloprovincialis, Scrobicularia plana and Ruditapes decussatus

The diet analysis for the four bivalves suggested that terrestrial POM is not an important component of the filter-feeders' diet and emphasized the contribution of the microphytobenthos as well as marine POM. This conclusion is independent on feeding behaviour,suspensivore $(C$. edule, M. galloprovincialis and R. decussatus) of facultative depositivore (S. plana), or position on the substrate, epibenthic ( $M$. galloprovincialis), superficial infaunal (C. edule) or subsuperficial infaunal (S. plana and $R$. decussatus). The differences in isotopic composition as well as between diets observed in the filter-feeders could be caused by differences in their ability to retain and select particles based on anatomic differences between species (Ward et al., 1998). 
In general, similar results have been observed using stable isotopes techniques: Crassotrea gigas in Marennes - Oléron Bay (Riera and Richard, 1997), C. edule in Marennes - Oléron Bay (Kang et al., 1999), Macoma balthica in Aiguillon Bay (Riera et al., 1999) and C. edule, R. decussatus and M. galloprovincialis in a similar ecosystem to this study (Page and Lastra, 2003).

The high contribution of microphytobenthos to the diet of filter-feeders has been emphasized using stable isotopes (Sauriau and Kang, 2000) and traditional analysis of gut content (Kamermans, 1994). The presence of microphytobenthos in the diet of epibenthic organisms suggests that resuspension processes caused by bottom currents could be important (Lucas et al., 2001) forced by tides or by the effect of the wind (deJonge and van Beusekom, 1995). Although this process can also resuspend detrital material derived from Z. marina, the contribution of this vascular plant to filter-feeders' diets is negligible, probably because of its poor nutritional quality (Williams, 1981). Resuspension could also make available detritus of other macroalgae and although the sediment, which compiles the contribution of macroalgae detritus, is not in the most plausible diet, its presence as a minority part of the diet cannot be discarded (Duggins and Eckman, 1997; Cardona et al., 2007; Riera et al., 2009).

\subsubsection{Sub-surface feeder: Arenicola marina}

The most plausible diet of A. marina included microphytobenthos and the macroalgae $E$. intestinalis and $F$. vesiculosus. One of the most important food sources for this species is the bacterial community in sediment (Grossman and Reichardt, 1991), which was not directly considered in this study, but was likely represented in the sediment sample which contains 
potential food sources such as meiofauna, microphytobenthos and detritus (Retraubun et al., 1996). The sediment was included as component of the A. marina's diet as a low plausibility food source (Table 3). This result can be caused by (1) the potential sources that were analyzed together (bacteria, meiofauna and detritus) and potential sources that were analyzed separately (microphytobenthos) having similar isotopic compositions; (2) a high percentage of refractory matter, not assimilable by A. marina, occurring in the sediment; for example terrestrial organic matter, that could also explain the low $\delta^{13} \mathrm{C}$ of the sediment (Table 2); and (3) the layer or sediment considered in this study, top $5 \mathrm{~mm}$, is not deep enough to evaluate the potential depth that A. marina can use. However, the strong contribution of microphytobenthos to the diet of this lugworm (Herman et al., 2000) and the ability to subduct surface sediment very rapidly in its burrow (Rijken, 1979) suggest that the surface sediment plays a more important role than the subsurface one as food source. The presence of macroalgae in the diet of A. marina is probably not related to direct assimilation of macroalgae fragments but it might be indirectly caused by the assimilation of epiphytic bacterial communities involved in the degradation of macroalgae detritus and not the detritus itself. In fact, macrophytes support bacterial production in Zostera spp. meadows (Boschker et al., 2000) and those bacterial communities have an isotopic signature similar to that of the assimilated substrate (see review in Jones et al., 2003). Therefore, a consequent transfer of the macroalgae's isotopic signature to the bacterial community's consumer is expected, i.e., A. marina. This hypothesis is in good agreement with the expected contribution of the bacterial community in sediment to the diet of A. marina (Grossman and Reichardt, 1991)." 


\subsubsection{Carnivores: Nucella lapillus, Gobius niger, Symphodus bailloni and Sepia officinalis}

The most plausible diet of N. lapillus included M. galloprovincialis and L. obtusata, although $M$. galloprovincialis could constitute the diet by itself according to a fractionation of 1.5 for $\delta^{13} \mathrm{C}$ and a range between 2.2 and 3.0 for $\delta^{15} \mathrm{~N}$. This diet is consistent with values observed in the literature, where barnacles and mussels were identified as the diet for this gastropod (Davenport et al., 1998). However, given the importance of barnacles in its diet (Dunkin and Hughes, 1984) and the absence of that crustacea in this study for methodological reasons -small size of available barnacles in the area-, the most plausible diet might reflect only partially the trophic relationships of the dogwhelk.

The most plausible diet for G. niger included S. plana, A. marina, Littorina spp. and N. lapillus, which is in good agreement with the literature, where the species is described as a feeding generalist (Whitehead et al., 1986; Fjosne and Gjosaeter, 1996). According to a recent review, Mollusca, Crustacea and Polychaeta constitute of $98.73 \%$ of its diet (Filiz and Togulga, 2009), however in this study the crustaceans Gammarus sp. and P. adspersus are not in the most plausible diet. The absence of crustaceans could be a limitation in the number of species considered in this study, and the analysis of other crustaceans could include them in the most plausible diet. G. niger is an example where the ability of stable isotopes to discriminate between food sources is limited because only two isotopes are available.

The same food sources suggested for G. niger were identified as the most plausible diet for $S$. bailloni, which is consistent with the diet observed for S. melops in the same ecosystem 
(Fernández, 1995) and S. tinca in the sourthern coast of Tunisia (Ouannes-Ghorbel and Bouain, 2006), showing the highly diversified feeding behaviour of this fish.

The most plausible diet of $S$. officinalis is P. adspersus and POM larger than $200 \mu \mathrm{m}$ for individuals smaller than $67 \mathrm{~mm}$ (DML); P. adspersus, G. niger and Gammarus sp. for individuals between 67 and $120 \mathrm{~mm}$; and G. niger and Gammarus sp. for individuals larger than $120 \mathrm{~mm}$. These diets are in good agreement with the patterns observed by Castro and Guerra (1990) for the same size classes. Both studies show that Palaemon sp. is an important food source for the two smaller groups and its contribution decreases in the larger group. On the contrary, the contribution of $G$. niger increases with the $S$. officinalis size. One of the most important food sources, especially for larger individuals, is the portunid, which has not been analyzed in the present study. Ignoring this important food source may have falsely increased the plausibility of detecting in the model the crustacean Gammarus sp., which a priori should be a less plausible source. Stable isotope analysis improves on gut content studies, which would not have been able to detect the presence of marine POM in the most plausible diet of the smaller group (Blanc et al., 1998; Blanc and Daguzan, 2000), as a consequence of the difficulty in identifying small particles.

\subsubsection{Omnivores: Gammarus sp. and Palaemon adspersus}

The most plausible diet of Gammarus sp. included sediment, microphytobenthos and $E$. intestinalis. Gammarus sp. is a generalist species in terms of food behaviour (Delong et al., 1993), with filamentous algae, fine detritus and diatoms as preferential food sources (Delong et 
al., 1993; Lotze and Worm, 2000), which is in good agreement with the results observed in the present study.

In the case of $P$. adspersus, the most plausible diet included molluscs (S. plana, L. littorea and $L$. obtusata) and macroalgae (Ulva spp. and A. nodosum), which differs from results obtained from gut content analysis of this species in the same geographical area (Figueras, 1986). In the latter study, marine POM and small crustaceans like Gammarus sp. were identified as the preferential food sources, although molluscs and macroalgae are also identified as possible food sources. These differences can be caused by the limitation of the isotopes in discriminating between a wide set of possible food sources as in the cases of G. niger and S. bailloni.

\section{$\underline{4.3 \text { Analysis of organic matter sources }}$}

The structure of the studied trophic web can be described in a stable isotope space as a triangle in the plane $\delta^{13} \mathrm{C}-\delta^{15} \mathrm{~N}$, abscissa - ordinate respectively (Fig. 3). The altitude of the triangle represents the difference in trophic level between the organic source and the apex consumers and the wide $\delta^{13} \mathrm{C}$ base illustrates the high variability in isotope composition between the different sources of organic matter. This trophic structure describes a community with a high diversity of organic matter sources, although the contribution of each source varies depending on the consumer, as is suggested by the most plausible diets (Table 3, Fig. 3). The results emphasized the important contribution of microphytobenthos as a food source for several consumers (Table 3, Fig. 5), because microphytobenthos were one of the most plausible sources for herbivores $(L$. littorea and L. obtusata), omnivores (Gammarus sp. and A. marina) and all of the filter-feeders 
(C. edule, R. decussatus, S. plana and M. galloprovincialis). This is in good agreement with other studies that demonstrated the importance of microphytobenthos to estuarine benthic organisms (Herman et al., 2000). On the contrary, although Z. marina is the dominant species in the study area in terms of biomass, its contribution seems to be limited to L. littorea, and probably channelized indirectly through epiphytic organisms, which have an isotopic composition similar to Z. marina (Winning et al., 1999). This small contribution could be caused by its low digestibility and nutritive quality (Hemminga and Duarte, 2000), although its contribution through detritivore trophic chains cannot be discarded (Alongi, 1998).

Similar to Z. marina and contrary to marine POM larger than $20 \mu \mathrm{m}$, marine POM below $20 \mu \mathrm{m}$ contributed less to the consumers' most plausible diets, especially in the case of filter-feeders, which are known to consume particulates in this size range (Møhlenberg and Riisgård, 1978). A detailed study is necessary to investigate possible reasons for the unexpectedly low contribution, but it could be caused by (1) the described methodology or (2) selective retention of particles below $20 \mu \mathrm{m}$. In the first case, using higher fractionation for ${ }^{13} \mathrm{C}$ would allow this food source to be included in the most plausible diet of filter-feeders. The diet analysis protocol described in this study suggests as the most plausible source the closest one to the consumer in the plane $\delta^{13} \mathrm{C}$ $-\delta^{15} \mathrm{~N}$, which could be the reason for discarding smaller POM in place of larger fractions. In the second case, selective retention of particles from the whole fraction below $20 \mu \mathrm{m}$ (Ward et al., 1998; Martineau et al., 2004) could result in a differential isotopic composition of the retained particles compared to the whole fraction, and therefore the isotopic composition of the marine POM below $20 \mu \mathrm{m}$ would not be representative of the ingested fraction. 
Another potential food source, terrestrial POM below $60 \mu \mathrm{m}$, is not relevant in the most plausible diets (TER in Table 3 and Fig. 5). The isotopic composition of this source is similar to the sediment (Table 2), therefore it could be assumed that the sediment is derived, at least partially, from terrestrial detritus. However, the indirect contribution of terrestrial POM to the most plausible diets is still not significant given the low plausibility of the sediment as a food source. In spite of this result, the contribution of the terrestrial matter through dissolved matter cannot be discarded. Marine POM and macroalgae $\delta^{15} \mathrm{~N}$ values (Table 2) correspond with those found in other geographical areas with intermediate values of anthropogenic wastewater input (Cole et al., 2004). Wastewater discharge has also been considered as the cause of high $\delta^{15} \mathrm{~N}$ values on other areas of the Northwest Iberian Peninsula (Bode et al., 2006). The studied Z. marina meadow is on the Eastern bank of the San Simón Bay, where the $85 \%$ (35,000 people) of the total population in the bay is widely spread along the coastline as well as the Oitavén-Verdugo River discharges wastewater from the other minor populations located in its fluvial basin (Fig. 1), which could cause the enrichment in $\delta^{15} \mathrm{~N}$ compared to areas without anthropogenic influence. However, the use of recycled nitrogen within the bay could be an alternative hypothesis to wastewater contribution for explaining the $\delta^{15} \mathrm{~N}$ enrichment (Riera et al., 2000). This was observed in the Schelde Estuary, where suspended organic matter composition could not be explained in terms of conservative mixing of riverine and terrestrial sources on the one hand and marine sources on the other one suggesting a significant contribution of autochthonous production (Middelburg and Nieuwenhuize, 1998). Although the characterization of anthropogenic sources in this area is challenging given human population distribution and the 
consequent diffusive inputs, further research is necessary to determine the contribution of urbanization and local production as well as nutrient recycling.

\section{$\underline{4.4 \text { Conclusions }}$}

The similarities between the results presented here and those from other studies based on similar trophic webs (Middelburg et al., 2000; Sauriau and Kang, 2000; Page and Lastra, 2003; Jaschinski et al., 2008) suggest that the described protocol, which takes into account the fractionation uncertainty and is based on both linear mixing and Euclidean distance models, is a feasible alternative to elucidate the most plausible trophic relationships in complex trophic webs. The application of this protocol to an intertidal flat dominated by Z. marina emphasized the importance of local primary production, especially microphytobenthos production, which could be available for several primary consumers through resuspension forced by tidal hydrodynamic.

\section{ACKNOWLEDGEMENTS}

This research was supported by Xunta de Galicia (PGDIDT99PXI30104A). We thank L. Pombar for assistance in the field and laboratory.

\section{REFERENCES}

Adams, T.S., Sterner R.W., 2000. The effect of dietary nitrogen content on trophic level $\mathrm{N}^{15}$ enrichment. Limnol. Oceanogr. 45, 601-607.

Alongi, D.M., 1998. Coastal Ecosytem Processes. CRC Press, Boca Ratón. 
Álvarez-Iglesias, P., Rubio, B., Pérez-Arlucea, M., 2006. Reliability of subtidal sediments as "geochemical recorders" of pollution inputs: San Simón Bay (Ría de Vigo, NW Spain). Estuar. Coast. Shelf Sci. 70, 507-521.

Barker, K.M., Chapman, A.R.O., 1990. Feeding preferences of periwinkles among four species of Fucus. Mar. Biol. 106, 113-118.

Ben-David, M., Schell, D.M., 2001. Mixing models in analyses of diet using stable isotopes: a response. Oecologia 127, 180-184.

Blanc, A., Pinczon Du Sel, G., Daguzan, J., 1998. Habitat and diet of early stages of Sepia officinalis L. (Cephalopoda) in Morbihan Bay, France. J. Moll. Stud. 64, 263-274.

Blanc, A., Daguzan, J., 2000. Size selectivity in the diet of the young cuttlefish Sepia officinalis (Mollusca: Sepiidae). J. Mar. Biol. Ass. U.K. 80, 1137-1138.

Bode, A., Álvarez-Osorio, M.T., Varela, M., 2006. Phytoplankton and macrophyte contributions to littoral food webs in the Galician upwelling estimated from stable isotopes. Mar. Ecol. Prog. Ser. 318, 89-102.

Boschker, H.T.S., Wielemaker, A., Schaub, B.E.M., Holmer, M., 2000. Limited coupling of macrophyte production and bacterial carbon cycling in the sediments of Zostera spp. meadows. Mar. Ecol. Prog. Ser. 203, 181-189.

Bunn, S.E., N.R. Loneragan, Kempster, M.A., 1995. Effects of acid washing on stable isotope ratios of $\mathrm{C}$ and $\mathrm{N}$ in penaeid shrimp and seagrass: Implication for food web studies using multiple stable isotopes. Limnol. Oceanogr. 40, 622-625. 
Cardona, L., Revelles, M., Sales, M., Aguilar, A., Borrell, A., 2007. Meadows of the seagrass Posidonia oceanica are a significant source of organic matter for adjoining ecosystems. Mar. Ecol. Prog. Ser. 335, 123-131.

Carreon-Martinez, L., Heath, D.D., 2010. Revolution in food web analysis and trophic ecology: diet analysis by DNA and stable isotope analysis. Mol. Ecol. 19, 25-27.

Castro, B.G., Guerra, A., 1990. The diet of Sepia officinalis (Linnaeus, 1758) and Sepia elegans (D’Orbigny, 1835) (Cephalopoda, Sepioidea) from the Ría de Vigo (NW Spain). Sci. Mar. $54,375-388$.

Caut, S., Angulo, E., Courchamp, F., 2009. Variation in discrimination factors $\left(\delta^{15} \mathrm{~N}\right.$ and $\left.\delta^{13} \mathrm{C}\right)$ : the effect of diet isotopic values and applications for diet reconstruction. J. App. Ecol. 46, 443-453.

Cloern, J.E., Canuel, E.A., Harris, D., 2002. Stable carbon and nitrogen isotope composition of aquatic and terrestrial plants of the San Francisco Bay estuarine system. Limnol. Oceanogr. 47, 713-729.

Cohen, J.E., Briand, F., Newman, C.M., 1990. Community food webs: data and theory. SpringerVerlag, Berlin.

Cole M.L., Valiela I., Kroeger K.D., Tomasky, G.L., Cebrian, J., Wigand, C., McKinney, R.A., Grady, S.P., Carvalho da Silva, M.H., 2004. Assessment of a $\delta^{15} \mathrm{~N}$ isotopic method to indicate anthropogenic eutrophication in aquatic ecosystems. J. Environ. Qual. 33, 124132.

Couch, C.A., 1989. Carbon and nitrogen stable isotopes of meiobentos and their food resources. Estuar. Coast. Shelf Sci. 28, 433-441. 
Currin, C.A., Newell, S.Y., Paerl, H.W., 1995. The role of standing dead Spartina alterniflora and benthic microalgae in salt marsh food webs: considerations based on multiple stable isotope analysis. Mar. Ecol. Prog. Ser. 121, 99-116.

Dang, C., Sauriau, P.G., Savoye, N., Caill-Milly, N., Martinez, P., Millaret, C., Haure, J., de Montaudouin, X., 2009. Determination of diet in Manila clams by spatial analysis of stable isotopes. Mar. Ecol. Prog. Ser. 387, 167-177.

Davenport, J., Moore, P.G., Magil, S.H., Fraser, L.A., 1998. Enhanced condition in dogwhelks, Nucella lapillus (L.) living under mussel hummocks. J. Exp. Mar. Bio. Ecol. 230, 225-234. de Jonge, V.N., Van Beusekom, J.E.E., 1995. Wind- and tide-induced resuspension of sediment and micromicrophytobenthos from tidal flats in the Ems estuary. Limnol. Oceanogr. 40, $766-778$.

De Lange, H.J., Van den Brink, N.W., 2006. Literature review of available techniques to characterize marine and estuarine food webs; with emphasis for application in the model OMEG. Wageningen, Alterra, Alterra-Rapport 1372.

Delong, M.D., Summers, R.B., Thorp, J.H., 1993. Influence of food type on the growth of a riverine amphipod, Gammarus fasciatus. Can. J. Fish. Aquat. Sci. 50, 1891-1896.

DeNiro, M.J., Epstein, S., 1978. Influence of diet on the distribution of carbon isotopes in animals. Geochim. Cosmochim. Acta 42, 495-506.

DeNiro, M.J., Epstein, S., 1981. Influence of diet on the distribution of nitrogen isotopes in animals. Geochim. Cosmochim. Acta 45, 341-351. 
Dubois, S., Blin, J.-L., Bouchaud, B., Lefebvre, S., 2007. Isotope trophic-step fractionation of suspension-feeding species: implications for food partitioning in coastal ecosystems. J. Exp. Mar. Biol. Ecol. 351, 121-128.

Duggins, D.O., Eckman, J.E., 1997. Is kelp detritus a good food for suspension feeders? Effects of kelp species, age and secondary metabolites. Mar. Biol. 128, 489-495.

Dunkin, S.d.B., Hughes, R.N., 1984. Behavioural components of prey-selection by dogwhelks, Nucella lapillus (L.), feeding on barnacles, Semibalanus balanoides (L.), in the laboratory. J. Exp. Mar. Biol. Ecol. 79, 91-103.

Fantle, M.S., Dittel, A.I., Schwalm, S.M., Epifanio, C.E., Fogel, M.L., 1999. A food web analysis of the juvenile blue crab, Callinectes sapidus, using stable isotopes in whole animals and individual amino acids. Oecologia 120, 416-426.

Fernández, A., 1995. Estructura y dinámica trófica de Symphodus melops (Pisces, Labridae) en la Ría de Vigo. Galicia (NW-España). Tesis doctoral, Universidad de Santiago de Compostela.

Figueras, A., 1986. Alimentación de Palaemon adspersus (Rathke, 1837) y Palaemon serratus (Pennant, 1777) (Decapoda: Natantia) en la ría de Vigo (N.O. España). Cah. Biol. Mar. 27, 77-90.

Filiz, H., Togulga, M., 2009. Age and growth, reproduction and diet of the Black goby, (Gobius niger) from Aegean Sea, Turkey. Journal of FisheriesSciences.com 3, 243-265.

Fjosne, K., Gjosaeter, J., 1996. Dietary composition and the potential of food competition between 0-group cod (Gadus morhua L.) and some other fish species in the littoral zone. ICES J. Mar. Sci. 53, 757-770. 
France, R.L., Peters, R.H., 1997. Ecosystem differences in the trophic enrichment of ${ }^{13} \mathrm{C}$ in aquatic food webs. Can. J. Fish. Aquat. Sci. 54, 1255-1258.

Fry, B., Parker, P.L., 1979. Animal diet in Texas seagrass meadows: $\delta^{13} \mathrm{C}$ evidence for the importance of benthic plants. Estuar. Coast. Shelf Sci. 8, 499-509.

Fry, B., Sherr, E.B., 1984. $\delta^{13} \mathrm{C}$ measurements as indicators of carbon flow in marine and freshwater ecosystems. Contrib. Mar. Sci. 27, 13-47.

Gannes, L.Z., O’Brien, D.M., Del Río, C.M., 1997. Stable isotopes in animal ecology: assumptions, caveats, and a call for more laboratory experiments. Ecology 78, 1271-1276.

Gannes, L.Z., Del Río, C.M., Koch, P., 1998. Natural abundance variations in stable isotopes and their potential uses in animal physiological ecology. Comp. Biochem. Physiol. 119, 725737.

Grossman, S., Reichardt, W., 1991. Impact of Arenicola marina on bacteria in intertidal sediments. Mar. Ecol. Prog. Ser. 77, 85-93.

Haines, E.B., Montague, C.L., 1979. Food sources of estuarine invertebrates analyzed using C13/C12 ratios. Ecology 60, 48-56.

Hawkins, S.J., Hartnoll, R.G., 1983. Grazing of intertidal algae by marine invertebrates. Oceanogr. Mar. Biol. Ann. Rev. 21, 195-282.

Hemminga, M.A., Duarte, C.M., 2000. Seagrass ecology. Cambridge University Press, Cambridge.

Herman, P.M.J., Middelburg, J.J., Widdows, J., Lucas, C.H., Heip, C.H.R., 2000. Stable isotopes as trophic tracers: combining field sampling and manipulative labeling of food resources for macrobenthos. Mar. Ecol. Prog. Ser. 204, 79-92. 
Hsieh, H.L., Kao, W.-Y., Chen, C.-P., Liu, P.-J., 2000. Detrital flows through the feeding pathway of the oyster (Crassostrea gigas) in a tropical shallow lagoon: $\delta^{13} \mathrm{C}$ signals. Mar. Biol. 136, 677-684.

Hughes, J.E., Deegan, L.A., Peterson, B.J., Holmes, R.M., Fry, B., 2000. Nitrogen flow through the food web in the oligohaline zone of a New England Estuary. Ecology 81, 433-452.

Hunter, J., 1981. Feeding preferences and competitive herbivory studies on two species of periwinkles, Littorina obtusata and Littorina littorea. Biol. Bull. 161, 328.

Jaschinski, S., Brepohl, D.C., Sommer, U., 2008. Carbon sources and trophic structure in an eelgrass Zostera marina bed, based on stable isotope and fatty acid analyses. Mar. Ecol. Prog. Ser. 358, 103-114.

Jones, W.B., Cifuentes, L.A., Kaldy, J.E., 2003. Stable carbon isotope evidence for coupling between sedimentary bacteria and seagrasses in a sub-tropical lagoon. Mar. Ecol. Prog. Ser. $255,15-25$.

Kamermans, P., 1994. Similarity in food source and timing of feeding in deposit- and suspension-feeding bivalves. Mar. Ecol. Prog. Ser. 104, 63-75.

Kang, C.K., Sauriau, P.G., Richard, P., Blanchard, G.F., 1999. Food sources of the infaunal suspension-feeding bivalve Cerastoderma edule in a muddy sandflat of Marennes-Oléron Bay, as determined by analyses of carbon and nitrogen stable isotopes. Mar. Ecol. Prog. Ser. $187,147-158$.

Kasai, A., Horie, H., Sakamoto, W., 2004. Selection of food sources by Ruditapes philippinarum and Mactra veneriformis (Bivalvia: Mollusca) determined from stable isotope analysis. Fish. Sci. 70, 11-20. 
Libes, S.M., 1992. An introduction to Marine Biogeochemistry. John Wiley and Sons, Inc., Singapore.

Lotze, H.K., Worm, B., 2000. Variable and complementary effects of herbivores on different life stages of bloom-forming macroalgae. Mar. Ecol. Prog. Ser., 200, 167-175.

Lubchenco, J., 1983. Littorina and Fucus: effects of herbivores, substratum heterogeneity, and plant escapes during succession. Ecology 64, 1116-1123.

Lucas, C.H., Banham, C., Holligan, P.M., 2001. Benthic-pelagic exchange of microalgae at a tidal flat. 2. Taxonomic analysis. Mar. Ecol. Prog. Ser. 212, 39-52.

Malet, N., Sauriau, P.-G., Ryckaert, M., Malestroit, P., Guillou, G., 2008. Dynamics and sources of suspended particulate organic matter in the Marennes-Oléron oyster farming bay: insights from stable isotopes and microalgae ecology. Estuar. Coast. Mar. Sci. 78, 576-586.

Mann, K.H., 2000. Ecology of Coastal Waters. Blackwell Science, Inc., Massachusetts.

Marbà, N., Holmer, M., Gacia, E., Barrón, C., 2006. Seagrass beds and coastal biogeochemistry, in: Larkum, A.W.S., Orth, R.J., Duarte, C.M. (Eds.), Seagrasses: Biology, ecology and conservation. Springer, The Netherlands, pp. 135-157.

Martineau, C., Vincent, W.F., Frenette, J.-J., Dodson, J.J., 2004. Primary consumers and particulate organic matter: Isotopic evidence of strong selectivity in the estuarine transition zone. Limnol. Oceanogr. 49, 1679-1686.

Michener, R.H., Schell, D.M., 1994. Stable isotope ratios as tracers in marine aquatic food webs, in: Lajtha, K., Michener, R.H. (Eds.), Stable isotopes in ecology and environmental science. Blackwell Scientific Publications, Oxford, pp. 138-157. 
Middelburg, J.J., Barranguet, C., Boschker, H.T.S., Herman, P.M.J., Moens, T., Heip, C.H.R., 2000. The fate of intertidal microphytobentos carbon: An in situ 13C-labeling study. Limnol. Oceanogr. 45, 1224-1234.

Middelburg, J.J., Nieuwenhuize, J., 1998. Carbon and nitrogen stable isotopes in suspended matter and sediments from the Schelde Estuary. Mar. Chem. 60, 217-225.

Møhlenberg, F., Riisgård, H.U., 1978. Efficiency of particle retention in 13 species of suspension feeding bivalves. Ophelia 17, 239-246.

Newman, J., 1991. The study of diet and trophic relationships through natural abundance $\mathrm{C}^{13}$, in: Coleman, D.C., Fry, B. (Eds.), Carbon Isotope Techniques. Academic Press Inc., San Diego, pp., 201-218.

Nienhuis, P.H., Groenendisk, A.M., 1986. Consumption of eelgrass Zostera marina by birds and invertebrate: an annual budget. Mar. Ecol. Prog. Ser. 29, 29-35.

Nieuwenhuize, J., Maas, Y.E.M., Middelburg, J.J., 1994. Rapid analysis of organic carbon and nitrogen in particulate materials. Mar. Chem. 45, 217-224.

Ouannes-Ghorbel, A., Bouain, A., 2006. The diet of the peacock wrasse, Symphodus (Crenilabrus) tinca (Labridae), in the southern coast of Tunisia. Acta Adriat. 47, 175-182.

Page, H.M., Lastra, M., 2003. Diet of intertidal bivalves in the Ría de Arosa (NW Spain): evidence from stable $\mathrm{C}$ and $\mathrm{N}$ isotope analysis. Mar. Biol. 143, 519-532.

Pasquaud, S., Pillet, M., David, V., Sautour, B., Elie, P., 2010. Determination of fish trophic levels in an estuarine system. Estuar. Coast. Shelf Sci. 86, 237-246.

Peterson, B.J., Howarth, R.W., Garritt, R.H., 1984. Multiple stable isotopes used to trace the flow of organic matter in estuarine food webs. Science 227, 1361-1363. 
Peterson, B.J., Fry, B., 1987. Stable isotopes in ecosystem studies. Ann. Rev. Ecol. Syst. 18, 293-320.

Petraitis, P.S., 1983. Grazing patterns of the periwinkle and their effect on sessile intertidal organisms. Ecology 64, 522-533.

Phillips, D.L., Gregg, J.W., 2001. Uncertainly in source partitioning using stable isotopes. Oecologia 127, 171-179.

Phillips, D.L., Gregg, J.W., 2003. Source partitioning using stable isotopes: coping with too many sources. Oecologia 136, 261-269.

Phillips, D.L., Koch, P.L., 2002. Incorporating concentration dependence in stable isotope mixing models. Oecologia 130, 114-125.

Pinnegar, J.K., Polunin, N.V.C., 2000. Contributions of stable-isotope data to elucidating food webs of Mediterranean rocky littoral fishes. Oecologia 122, 399-409.

Pitt, K.A., Connolly, R.M., Meziane, T., 2009. Stable isotope and fatty acid tracers in energy and nutrient studies of jellyfish: a review. Hydrobiologia 616, 19-132.

Polunin, N.V.C., Pinnegar, J.K., 2002. Trophic ecology and the structure of marine food webs, in: Hart, P.J.B., Reynolds, J.D. (Eds.), Handbook of fish biology and fisheries. Blackwell Publishing, United Kingdom, pp. 301-320.

Ponsard, S., Arditi, R., 2000. What can stable isotopes $\left(\delta^{15} \mathrm{~N}\right.$ and $\left.\delta^{13} \mathrm{C}\right)$ tell about the food web of soil macro-invertebrates. Ecology 81, 852-864.

Post, D.M., Pace, M.L., Hairston Jr., N.G., 2000. Ecosystem size determines food-chain length in lakes. Nature 405, 1047-1049. 
Post, D.M., 2002. Using stable isotopes to estimate trophic position: models, methods, and assumptions. Ecology 83, 703-718.

Retraubun, A.S.W., Dawson, M., Evans, S.M., 1996. The role of the burrow funnel processes in the lugworm Arenicola marina (L.). J. Exp. Mar. Biol. Ecol., 202, 107-118.

Riera, P., Escaravage, C., Leroux, C., 2009. Trophic ecology of the rocky shore community associated with the Ascophyllum nodosum zone (Roscoff, France): A $\delta^{13} \mathrm{C}$ vs $\delta^{15} \mathrm{~N}$ investigation. Estuar. Coast. Shelf Sci. 81, 143-148.

Riera, P., Richard, P., 1997. Temporal variation of $\delta^{13} \mathrm{C}$ in particulate organic matter and oyster Crassostrea gigas in Marennes-Oléron Bay (France): effect of freshwater inflow. Mar. Ecol. Prog. Ser. 147, 10-115.

Riera, P., Stal, L.J., Nieuwenhuize, J., Richard, P., Blanchard, G., Gentil, F., 1999. Determination of food sources for benthic invertebrates in a salt marsh (Aiguillon Bay, France) by carbon and nitrogen stable isotopes: importance of locally produced sources. Mar. Ecol. Prog. Ser. 187, 301-307.

Riera, P., Stal, L.J., Nieuwenhuize, J., 2000. Heavy $\delta^{15} \mathrm{~N}$ intertidal benthic algae and invertebrates in the Scheldt Estuary (The Netherlands): Effect of river nitrogen inputs. Estuar. Coast. Shelf Sci. 51, 365-372.

Rijken, M., 1979. Food and food uptake in Arenicola marina. Neth. J. Sea Res. 13, 406-421.

Sauriau, P.G., Kang, C.-K., 2000. Stable isotope evidence of benthic microalgae-based growth and secondary production in the suspension feeder Cerastoderma edule (Mollusca, Bivalvia) in the Marennes-Oléron Bay. Hydrobiologia 440, 317-329. 
Schaal, G., Riera, P., Leroux, C., 2008. Trophic coupling between two adjacent benthic food webs within a man-made intertidal area: A stable isotopes evidence. Estuar. Coast. Shelf Sci. 77, 523-534.

Sheppard, S.K., Harwood, J.D., 2005. Advances in molecular ecology: tracking trophic links through predator-prey food-webs. Funct. Ecol. 19, 751-762.

Sommer, U., 2000. Benthic microalgal diversity enhanced by spatial heterogeneity of grazing. Oecologia 122, 284-287.

Suring, E., Wing, S.R., 2009. Isotopic turnover rate and fractionation in multiple tissues of red rock lobster (Jasus edwarsii) and blue cod (Parapercis colias): Consequences for ecological studies. J. Exp. Mar. Biol. Ecol. 370, 56-63.

Tieszen, L.L., Boutton, T.W., Tesdahl, K.G., Slade, N.A., 1983. Fractionation and turnover of stable carbon isotopes in animal tissues: Implications for $\delta^{13} \mathrm{C}$ analysis of diet. Oecologia $57,32-37$.

Törnblom, E., Sondergaard, M., 1999. Seasonal dynamics of bacterial biomass and production on eelgrass Zostera marina leaves. Mar. Ecol. Prog. Ser. 179, 231-240.

Vander Zanden, M.J., Rasmussen, J.B., 1999. Primary consumer $\delta^{13} \mathrm{C}$ and $\delta^{15} \mathrm{~N}$ and the trophic position of aquatic consumers. Ecology 80, 1395-1404.

Vander Zanden, M.J., Rasmussen, J.B., 2001. Variation in $\delta^{15} \mathrm{~N}$ and $\delta^{13} \mathrm{C}$ trophic fractionation: Implications for aquatic food web studies. Limnol. Oceanogr. 46, 2061-2066.

Yokoyama, H., Tamaki, A., Harada, K., Shimoda, K., Koyama, K., Ishihi, Y., 2005. Variability of diet-tissue isotopic fractionation in estuarine macrobenthos. Mar. Ecol. Prog. Ser. 296, 115-128. 
Ward, J.E., Levinton, J.S., Shumway, S.E., Cucci, T., 1998. Particle sorting in bivalves: in vivo determination of the pallial organs of selection. Mar. Biol. 131, 283-292.

Watson, D.C., Norton, T.A., 1987. The habitat and feeding preferences of Littorina obtusata (L.) and L. mariae Sacchi et Rastelli, J. Exp. Mar.Biol. Ecol. 112, 61-72.

Whitehead, P.J.P., Bauchot, M.-L., Hureau, J.-C., Nielsen, J., Tortonese, E., 1986. Fishes of the North-eastern Atlantic and the Mediterranean. United Nations Educational, Scientific and Cultural Organization, Paris.

Williams, P., 1981. Detritus utilization by Mytilus edulis. Estuar. Coast. Shelf Sci. 12, 739-746.

Winemiller, K.O., Polis, G., 1996. Food Webs: What do they tell us about the world?, in: Polis, G., Winemiller, K.O. (Eds.), Food Webs. Integration of patters and dynamics. Chapman and Hall, New York, pp. 1-22.

Winning, M.A., Connolly, R.M., Loneragan, N.R., Bunn, S.E., $1999 .{ }^{15} \mathrm{~N}$ enrichment as a method of separating the isotopic signatures of seagrass and its epiphytes for food web analysis. Mar. Ecol. Prog. Ser. 189, 289-294. 


\section{FIGURE LEGEND}

Figure 1. Location of study area and main cities, villages and rivers of Ría de Vigo drainage area.

Figure 2. Average isotopic composition of consumer (circle) and food sources (squares). A. If the ellipse defined by the standard deviation of the source included the consumer after correcting the fractionation, the source was considered as a potential diet of the consumer. B. The space delimited by both ellipses allows a mathematical explanation of the diet using linear mixing models, in the case of consumer 1 the contribution of each source is positive, however in the case of consumer 2 , one of the sources has a negative contribution, which makes no biological sense. C. The ellipse of theoretical standard deviation of the consumer calculated with the relative contribution of each source includes the straight line between the sources and therefore the sources can explain the consumer isotopic composition. D. The space delimited by the ellipses corresponds the area where the mixing models could explain the consumer isotopic composition. The dashed line represent the solutions considered in the present study.

Figure 3. Trophic web of San Simón. The arrows represent the most plausible consumer resource relationships. Dot lines group species with similar diet. 
Table 1. Structure of the table in which all the possible diets for a consumer are summarized according to the 9 combinations of fractionation and the possibility of including one, two or three food sources in the solution.

\begin{tabular}{|c|c|c|c|}
\hline $\begin{array}{l}\text { Fractionation } \\
\text { combination }\end{array}$ & $\begin{array}{c}\text { Diets with } 3 \text { fooc } \\
\text { sources }\end{array}$ & $\begin{array}{c}\text { Diets with } 2 \text { food } \\
\text { sources }\end{array}$ & $\begin{array}{c}\text { Diets with } 1 \text { food } \\
\text { source }\end{array}$ \\
\hline $0.5 \% \mathrm{C}, 2.2 \% \mathrm{~N}$ & & & \\
\hline $0.5 \% \mathrm{C}, 3.0 \% \mathrm{~N}$ & & & \\
\hline $0.5 \% \mathrm{C}, 3.8 \%{ }_{0} \mathrm{~N}$ & & & \\
\hline $1.0 \% \mathrm{C}, 2.2 \% \mathrm{~N}$ & & & \\
\hline $1.0 \% \mathrm{C}, 3.0 \% \mathrm{~N}$ & & & \\
\hline $1.0 \% \mathrm{C}, 3.8 \% \mathrm{oN}$ & & & \\
\hline $1.5 \% \mathrm{C}, 2.2 \% \mathrm{~N}$ & & & \\
\hline $1.5 \% \mathrm{C}, 3.0 \% \mathrm{~N}$ & & & \\
\hline $1.5 \% \mathrm{C}, 3.8 \% \mathrm{~N}$ & & & \\
\hline
\end{tabular}


Table 2. Studied samples, code used in consecutive figures, average values of $\delta^{13} \mathrm{C}$ and $\delta^{15} \mathrm{~N}$ as well as their standard deviations, Std. D. $\delta^{13} \mathrm{C}$ and Std. D. $\delta^{15} \mathrm{~N}$, and number of cases (n).

\begin{tabular}{lcccccc}
\hline \multicolumn{1}{c}{ Sample } & Cod & $\boldsymbol{\delta}^{\mathbf{1 3}} \mathbf{C}$ & $\begin{array}{c}\text { Std. D. } \\
\boldsymbol{\delta}^{\mathbf{1 3}} \mathbf{C}\end{array}$ & $\boldsymbol{\delta}^{\mathbf{1 5}} \mathbf{N}$ & $\begin{array}{c}\text { Std. D. } \\
\boldsymbol{\delta}^{\mathbf{1 5}} \mathbf{N}\end{array}$ & $\mathbf{n}$ \\
\hline Marine POM $>200 \mu \mathrm{m}$ & LAR & -19.31 & 1.391 & 7.44 & 0.913 & 18 \\
Marine POM $20-200 \mu \mathrm{m}$ & MID & -17.68 & 1.715 & 6.90 & 0.488 & 18 \\
Marine POM $<20 \mu \mathrm{m}$ & SMA & -21.29 & 1.377 & 6.13 & 0.736 & 20 \\
Terrestrial POM $<60 \mu \mathrm{m}$ & TER & -24.92 & 1.799 & 5.32 & 0.786 & 16 \\
Sediment & SED & -24.84 & 4.740 & 6.06 & 0.593 & 18 \\
Microphytobenthos & PB & -17.80 & 2.170 & 5.56 & 1.045 & 13 \\
Ascophyllum nodosum & AN & -16.11 & 0.943 & 9.39 & 0.499 & 18 \\
Enteromorpha intestinalis & EI & -16.28 & 2.205 & 8.43 & 0.742 & 12 \\
Fucus vesiculosus & FV & -15.80 & 1.254 & 8.71 & 0.599 & 18 \\
Ulva spp. & UL & -10.46 & 2.886 & 8.48 & 0.655 & 18 \\
Zostera marina & ZM & -8.34 & 0.691 & 7.22 & 0.607 & 18 \\
Littorina littorea from rocks & LLRO & -13.80 & 1.047 & 10.93 & 0.264 & 18 \\
Littorina littorea from Z. Marina & LLZO & -10.57 & 1.030 & 11.05 & 0.323 & 14 \\
Littorina obtusata & LO & -13.92 & 0.280 & 10.77 & 0.343 & 18 \\
Cerastoderma edule & CE & -16.20 & 0.483 & 9.53 & 0.509 & 15 \\
Mytilus galloprovincialis & MG & -17.14 & 0.455 & 8.98 & 0.700 & 18 \\
Scrobicularia plana & SP & -15.54 & 0.829 & 9.48 & 0.786 & 12 \\
Ruditapes decussatus & RD & -16.41 & 0.634 & 9.60 & 0.408 & 21 \\
Arenicola marina & AM & -15.02 & 0.604 & 11.21 & 0.864 & 18 \\
Gobius niger & GN & -13.92 & 0.784 & 13.39 & 0.389 & 15 \\
Nucella lapillus & NL & -15.34 & 0.614 & 11.85 & 0.393 & 6 \\
Sepia officinalis $<67$ mm & SOSMA & -12.49 & 0.489 & 13.57 & 0.344 & 10 \\
Sepia officinalis $67-120$ mm & SOMID & -15.43 & 0.653 & 12.72 & 0.483 & 10 \\
Sepia officinalis $>120$ mm & SOLAR & -15.67 & 0.985 & 12.69 & 0.571 & 10 \\
Symphodus bailloni & SB & -13.61 & 0.626 & 13.83 & 0.472 & 8 \\
Gammarus sp. & GM & -17.48 & 0.783 & 10.34 & 0.450 & 18 \\
Palaemon adspersus & PA & -12.66 & 0.508 & 12.92 & 0.368 & 18 \\
\hline & & & & & & \\
\hline
\end{tabular}


Table 3. Consumer (column) - Resource (row) trophic relationships. For each consumer are shown the food sources considered a priori as potential food sources (grey cells), those included on the most plausible diet $(\bullet)$ and less plausible diets $(\circ)$. See table 2 for consumer's code.

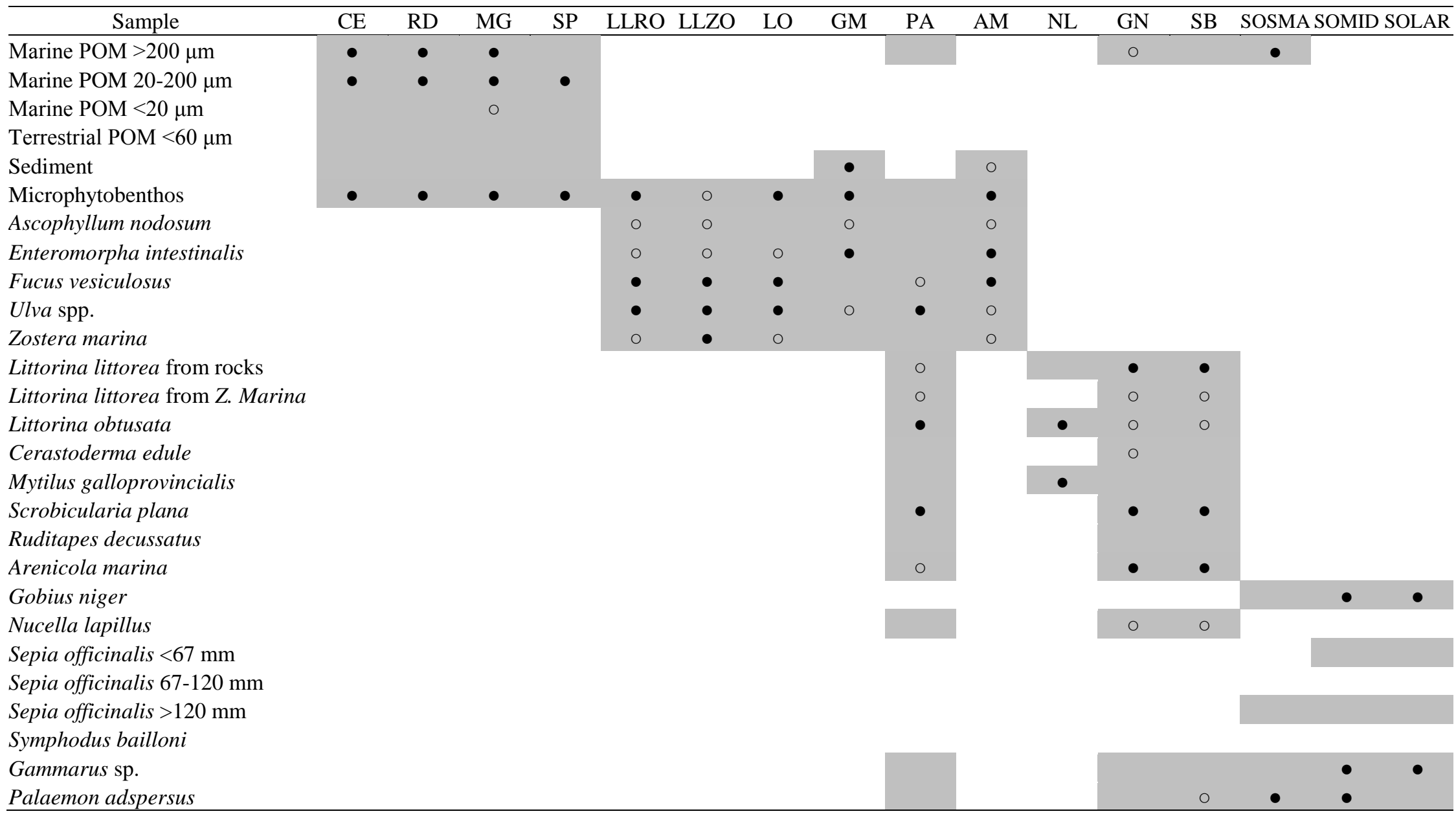




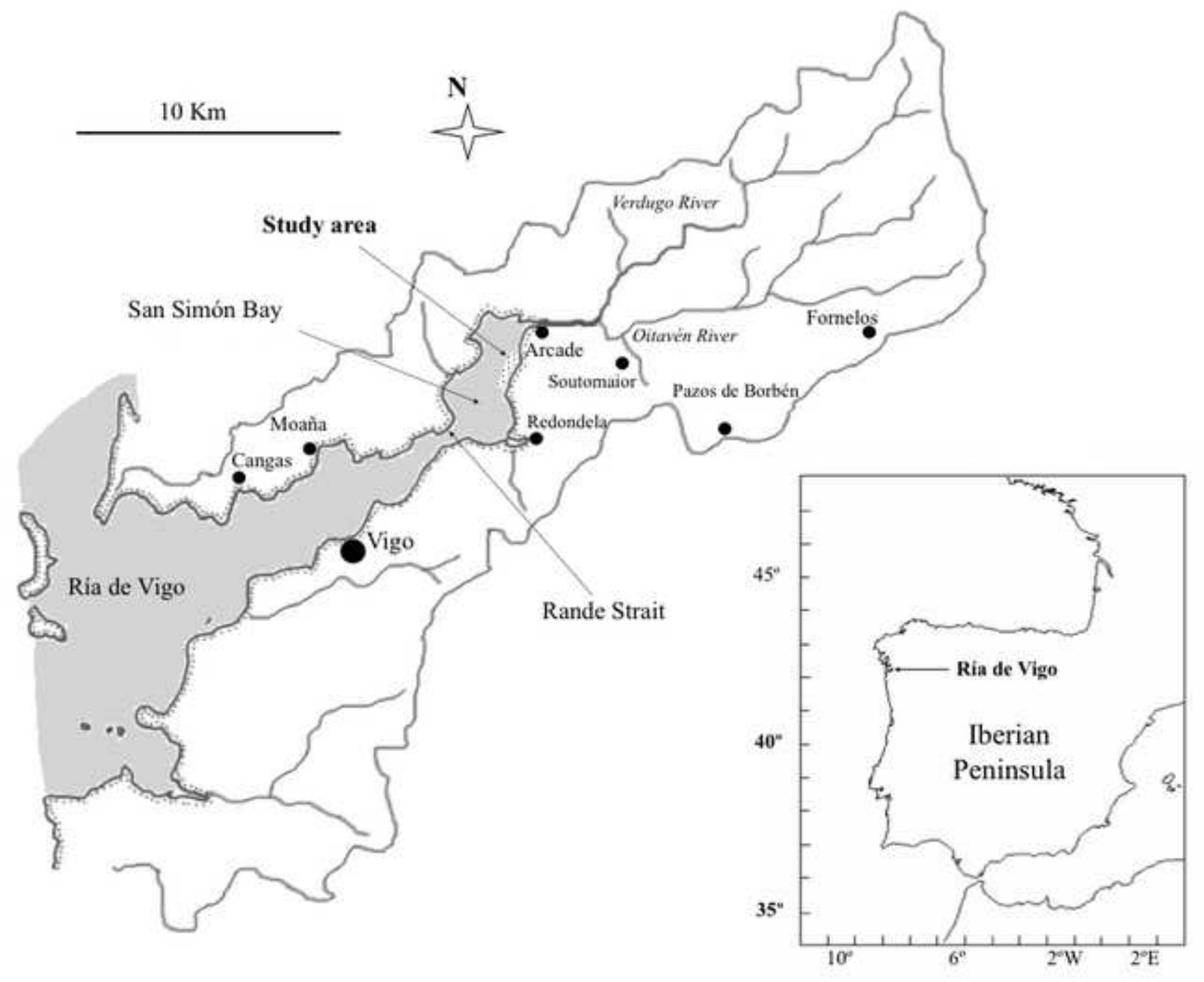


Click here to download high resolution image
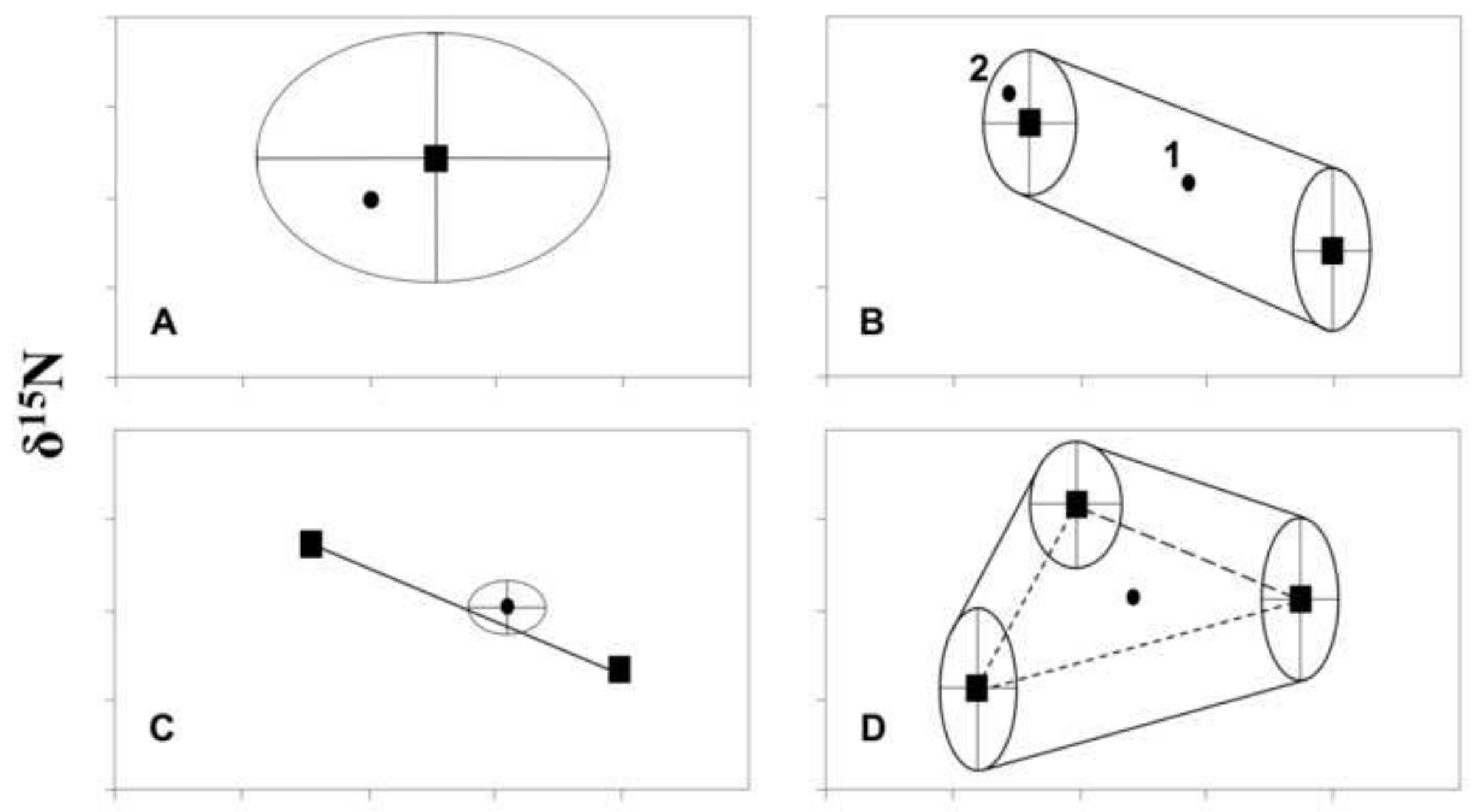

$\delta^{13} \mathrm{C}$ 


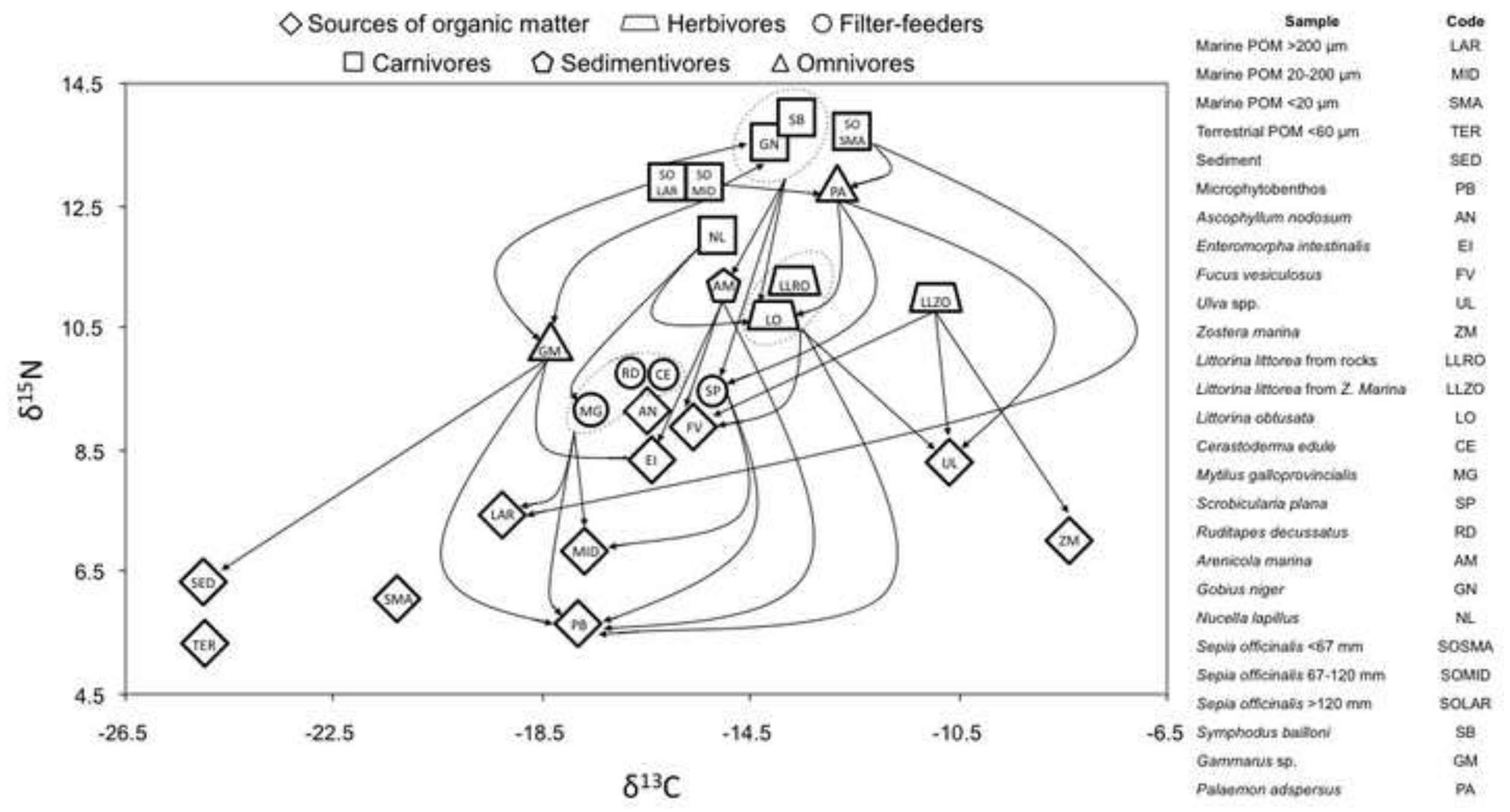

